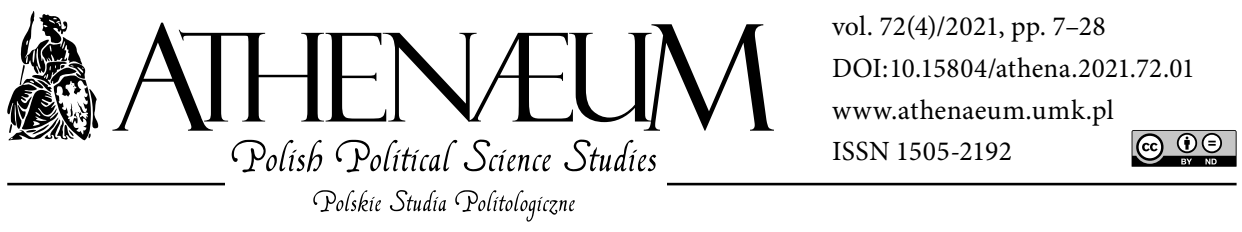

\title{
"BIRDS OF A FEATHER FLOCK TOGETHER": BIPOLARITY, HOMOPHILY AND INTRA-PARTY COMMUNICATION DEGREE OF POLISH MPS ON TWITTER
}

\author{
"CIAGNIE SWÓJ DO SWEGO". \\ BIPOLARNOŚĆ, HOMOFILIA I KOMUNIKACJA \\ WEWNĄTRZPARTYJNA POLSKICH POSŁÓW NA TWITTERZE
}

Jacek Nożewski* ㄱ, Paweł Baranowski** (우

-

Since the contemporary public sphere has largely moved online, Twitter has become the leading platform of political debate. Potentially harmful echo spheres, selective exposure and social media filter bubbles that limit individuals to their own opinions can be especially alarming when it concerns politicians. This paper aims to investigate the degree of homophily among Polish MPs, simultaneously indicating the way politicians form follower communication structures. The analysis of the data gathered from Twitter revealed observable elements of polarization at the political affiliation level, although the level of parliament chambers was found meaningless in that case. The Polish political Twittersphere is dominated by the two biggest parties, accurately reflecting parliament composition. The use of communication structure is examined throughout this paper, ultimately confirming the homo-
\end{abstract}

Współczesna sfera publiczna w dużej mierze przeniosła się do Internetu, a Twitter stał się wiodącą platformą debaty politycznej. Potencjalnie szkodliwe bańki informacyjne, które skutkują selektywną ekspozycją na wiadomości w mediach społecznościowych, ograniczają jednostki do ich własnych opinii, co może być szczególnie niepokojące, gdy dotyczy osób podejmujących decyzje polityczne. Celem niniejszego artykułu jest zbadanie wzajemnych relacji pomiędzy polskimi parlamentarzystami na Twitterze oraz stworzenie matrycy powiązań pomiędzy politykami reprezentującymi różne partie polityczne. Analiza danych empirycznych z Twittera udowodniła, że istnieją wysoce spolaryzowane struktury parlamentarzystów, które tworzą się w obrębie przynależności politycznej. Z perspektywy aktorów politycznych polska część Twittera zdominowana jest przez obóz

* University of Lower Silesia, Faculty of Applied Studies.

** University of Wrocław, Institute of Journalism and Social Communication. 
philic behavior of specific politicians' groups, especially in terms of mutual communication and its effectiveness.

Keywords: Poland; Twitter; political communication; social media; network analysis
Zjednoczonej Prawicy oraz Koalicję Europejską, a jej wewnętrzny podział stanowi odwzorowanie mandatów w parlamencie.

Słowa kluczowe: Polska; Twitter; komunikacja polityczna; media społecznościowe; analiza sieci

\section{INTRODUCTION}

Two years after Twitter was launched, with the successful utilization of microblogging during Barack Obama's presidential campaign in 2008 (Cogburn \& Espinoza-Vasquez, 2011), social networks have attracted the attention of politicians and public opinion worldwide, furthering the trend of Americanization (Schulz, 2014, p. 68) in political communication. Twitter is an Information Communication Technology tool with special meaning for political actors, and has been studied thoroughly from perspectives such as online campaigning (Ahmed, Jaidka, \& Cho, 2016; Stier et al., 2018), populist communication (Casero-Ripollés, Sintes-Olivella, \& Franch, 2017), and dissemination of information and civic engagement (Park, 2013). As a communicative space functioning within the dimensions of software, relations, and rules (Schmidt, 2014), Twitter is a venue of constant debate. Nonetheless, scholarly attention on analyzing political communication on social media is mostly focused on Western democracies (Matuszewski \& Szabó, 2019, p. 1).

Although focused on political interaction, many studies conducted outside the US have proven that politicians are using microblogging as a broadcasting tool (Poulakidakos \& Veneti, 2016, p. 137). Poland, as a late adopter of postmodern tools of political communication (Dobek-Ostrowska, 2017), is no exception. Polish electoral communication on Twitter can sometimes be called a monologue (Baranowski, 2015), with room for improvement in politicians' activity (Czyżowski \& Porębski, 2017, p. 177). Twitter has been argued as being the platform with the greatest politician and journalist presence (Woźniak, 2015). Furthermore, in 2020, over $76 \%$ of parliament members are active on Twitter. Thus, microblogging is exceptionally important from the perspective of political debate.

The public sphere in the era of social media should be rather understood as multiple "sphericules", where communication occurs between micro-publics (Bruns \& Highfield, 2015, p. 125). On Twitter, micro-publics consist of actors who 
are involved in multiple, mutual relationships. The nature of Twitter-mediated communication can manifest in various forms and activities. One of the crucial measures of the mutual connections between individuals on social media is reciprocity, simply defined as "the action of returning of similar acts" (Zhang, Dantu, \& Cangussu, 2009). Reciprocity as important to the functioning of virtual public spheres was also highlighted by Papacharissi (2008, p. 235). The act of returning symmetric (Cheng et al., 2011) actions on Twitter can be illustrated by following, tweeting, or liking. Hence, the main aim of this article is the analysis of the reciprocal relations between Polish MPs on the most popular microblogging platform in order to describe the level of homophily among them.

Homophily, as an essential concept explaining the essence of relations in social networks, assumes that people tend to connect based on their similarity (McPherson, Smith-Lovin, \& Cook, 2001, p. 416). In the context of this paper, this can be related with status and value homophily (Lazarsfeld \& Merton, 1954), where the occupation and political affiliation are dominant variables. However, the phenomenon of homophily has consequences in perception biases, such as filter bubbles or majority illusion (Lee et al., 2017), meaning that relations among MPs can result in partiality and prejudice in debate on Twitter. This ideological polarization is also enhanced by the phenomenon of selective exposure (Stroud, 2008). However, the original theory is rooted in the tendency of choosing the traditional media in accordance with one's personal beliefs, in the time of increased social media news consumption it is still highly relevant. Previous research proved that selective exposure affects Facebook users more than filter bubbles (Spohr, 2017), and the political predispositions are altering news selection on social media (Messing \& Westwood, 2014). Politicians as Twitter users can also selectively create and enhance the ties between other users based on the partisanship and ideological similarity. Given the fact that microblogging MPs has got the potential to influence public opinion (Jungherr, 2016) and they serve as the opinion leaders within this particular digital sphere, the patterns of their reciprocal behavior and news consumption can affect the society as a whole.

\section{PUBLIC SPHERE IN POLAND}

The 2015 parliamentary elections were a breakthrough for the nationalconservative Law and Justice (L\&J) party, which was the first party to form a majority government since 1991 . In 2019 , the L\&J party repeated this with 
another electoral victory, but this has also increased political polarization in Polish politics. The re-election of the L\&J party was determined by the - also polarizing - generous social policy (Marciniak, 2020). The most evident example of social welfare that was widely discussed by the competing parties and media was the " $500+$ " family subsidy program, which granted 500 Polish Złoty (approx. 110 EUR) to parents for each child under the age of 18 . The socioeconomic reasons for L\&J supremacy were also highlighted by Szczerbiak (2019a), who further pointed out that the strong indication of national and traditional values both in the electoral campaign and political program was the strong incentive for a substantial portion of Polish voters. This notion was again visible in the research by Szafraniec \& Grygieńć (2019), also pointing out the issue of cultural aversion to foreign elements, especially immigrants from the Middle East. On the other hand, the largest opposition party - Civic Platform - despite sharing Christian-Democratic ideological roots with Law and Justice, has not been able to unite voters and win elections for a decade. Analyses indicate that the reason for this may be the lack of credibility of the party and the absence of charismatic leadership (Szczerbiak, 2019b). Hence, the parliamentary elections resulted in consolidation of two main political dimensions in Poland. The first dimension was the United Right, an informal political alliance led by the ruling party with United Poland and Agreement as minor coalition partners. The second, opposing dimension consists of the major Civic Coalition (with Civic Platform as a leader), the Left, Polish Coalition, and Confederation, which usually vote against each bill proposed by L\&J. Although Poland is most certainly not an example of a twoparty system, the Polish parliament is divided bipolarly. The electorates of the two biggest Polish political parties are also strongly polarized. Zagała (2020) argues that due to the intensity, ubiquity and longevity of the conflict between the L\&J and the CP electorate, one can even speak of a two-tribe structure of Polish society.

As mentioned above, homophily determines the patterns of connections between people given certain traits and attributes. Aligned with social influence, it results in assortative mixing, which creates an even stronger tendency to maintain connectivity (Newman, 2012; Šćepanović et al., 2017, p. 1). Moreover, strong personal ties in political parties can also enhance this effect, as online communication tends to occur more often among those who know each other offline (Uslaner, 2004, p. 24). Consequently, this phenomenon can lead to the formation of ideological echo chambers (Del Valle \& Bravo, 2018, p. 1716), which can be harmful for the democratic process (Sunstein, 2009). Previous work on 
echo chamber effects on Twitter is mostly focused on the relations between the individual users (i.e., Bruns, 2017; Matuszewski \& Szabó, 2019) and citizens as voters (Vaccari et al., 2016). Politicians as Twitter users and especially the reciprocal nature of their interactions has been the subject of research by Del Valle and Bravo (2018) who aimed to study polarization on Twitter among Catalan MPs. Hong and Kim (2016) focused on verifying the political polarization on social media between members of the U.S. House of Representatives. Despite the several attempts to verify the existence of echo chambers on social media between politicians, no study so far has addressed the mutual connections between Polish politicians on Twitter.

Robert Dahl's On Democracy refers to alternative sources of information as a key institution of modern representative democracy (1998, p. 86). Massa (2011, p. 158) argues that digitized society massively using social network services brings the risk of segmentation into groups that do not communicate with people having different views. Polish MPs on Twitter are subject to a constant process of creating and consuming opinions. If they are not exposed to anything other than conforming opinions, they may listen only to the echoes of their own voices, which carries the threat of confirming their belief in the unquestionable legitimacy of their actions. Therefore, vulnerability of political actors to digital echo chambers may have critical impact for the whole society.

The main aim of this research was to investigate the online behaviour of Polish MPs on Twitter in terms of maintaining connections with other MPs. The complexity of reciprocity mechanisms on Twitter has served as a departure point for this analysis, where we aim to describe the structure of mutuality. This led us to several questions concerning the way politicians form mutual and asymmetrical relations or tendencies to connect with others bearing similar characteristics.

\section{METHOD}

Network analysis based on mathematical graph theory was the leading approach for the research. Social network analysis provides a representation of a social network as a model of a social system consisting of actors and ties between them (Iacobucci, 1994, p. 93). The key for the analysis that includes social actors and their connections is a mathematical object expressed in the form of graph in which a set of nodes represent actors, and edges between a pair of nodes reflect the presence of a given relationship (Carrington, 2014, p. 36). The statistics 
of a given graph highlight the quantitative nature of the analysis (Brandes \& Erlebach, 2005), however qualitative aspects of a real social network can be also represented, for instance, in the form of specific attributes given to nodes (Scott, 2000; Carrington, 2014; Hollstein, 2011).

The project was particularly focused on the investigation of homophilic communication behaviour in Polish Members of Parliament; hence the entire research process was compatible with the network approach, and consisted of three stages: 1) data verification and pre-processing, 2) R programming language use for data retrieval, and 3) network data analysis. The first step was oriented at obtaining the data for the analysis. We gathered the names and Twitter screen names of all actively microblogging Polish MPs from the official website of the Polish Parliament. The dataset was limited only to deputies of current Sejm (Lower House) and Senate (Upper House) of ninth and tenth cadence respectively. Party affiliation was used as a key attribute variable for the analysis. To process the data and match the screen names, we prepared a custom code in R, which used accessible data on Twitter REST API. Our R script relied on filtering functions and extracting data directly from the accounts of political actors. After the data had been extracted, we filtered out the follower bases of Polish MPs from all the users who did not have the status of a MP. Alternately, for the data analysis, we used several multifaceted filters aiming to obtain a complete and deep picture of political communication network structure limited to current deputies and senators.

The network approach required information input consisting of source and target data. Thus, it was indispensable to convert obtained data from simple follower sets into an edges list that included source and target data to obtain empirical material accessible for the proper analysis process. Reflections on users' homophilic behaviour and their importance in followers' network formation led to the formulation of the following research questions:

RQ1: Does the partisanship factor positively affect the degree of network homophily?

RQ2: To what extent do Polish MPs maintain mutual and asymmetrical relations?

RQ3: Is polarization observable in the context of communication structure?

RQ4: What is the degree of connectivity of particular party-affiliated groups and how does it affect the degree of homophily?

RQ5: To what extent do Polish MPs appearing on Twitter use the follower networks for maintaining contact with other politicians? 
The research did not include detailed information about particular politicians. Local data were condensed and used merely to picture the general communication landscape of Polish MPs on Twitter. The time range of the analysis encompassed intense political debate on presidential elections and the COVID19 issue, however these did not become main foci of the research.

\section{DATA}

The preliminary analysis allowed highlighting dependencies appropriated for the network data and drew a general picture of a communication structure. The entire network consisted of 429 actors connected by 27741 edges (Table 1). The data encompassed users' political affiliation (see Appendix for the list of political parties/alliances) as well, hence one can clearly recognize larger and smaller groups within the network. However, the aim of the study is slightly different, and goes beyond the basic structural properties of the graph. The data overview provided indispensable information on which groups of politicians were more or less observed by the others.

Table 1. Polish MPs' Network Data

\begin{tabular}{|l|c|c|c|c|}
\hline $\begin{array}{c}\text { Party } \\
\text { affiliation }\end{array}$ & $\begin{array}{c}\text { Sejm } \\
\text { (Lower House) }\end{array}$ & $\begin{array}{c}\text { Sejm } \\
\text { average prestige }\end{array}$ & $\begin{array}{c}\text { Senate } \\
\text { (Upper House) }\end{array}$ & $\begin{array}{c}\text { Senate } \\
\text { average prestige }\end{array}$ \\
\hline CC & $120(.89)$ & $.19(.14)$ & $27(.63)$ & $.14(.11)$ \\
\hline CONF & $11(1.00)$ & $.11(.09)$ & --- & -- \\
\hline PC & $25(.83)$ & $.13(.12)$ & $2(.66)$ & $.20(.07)$ \\
\hline L & $41(.84)$ & $.11(.09)$ & $1(.50)$ & $.04(-)$ \\
\hline GM & $1(1.00)$ & $.02(-)$ & --- & $.22(.17)$ \\
\hline IND & --- & --- & $3(1.00)$ & $.08(.12)$ \\
\hline UR & $177(.75)$ & $.15(.13)$ & $21(.44)$ & \\
\hline Nodes $N$ & $375(.82)$ & & $54(.54)$ & \\
\hline Edges $N$ & 22550 & & 455 & \\
\hline
\end{tabular}

Note: Numbers in parentheses mean the proportion of deputies integrated into the analysis who possess Twitter accounts and all deputies active in 2020 parliament. Edges $N$ depicts inner ties for Sejm and Senate separately.

The degree of prestige is one of several basic network measures, and provides information on the tendency to receive nominations or choices from other actors 
within the network. The so-called "relative indegree" is a proportion of all actors who choose one, hence a larger index represents more prestigious actors (Wasserman \& Faust, 2006, pp. 202-203). Deputies from CC are more prestigious (have more followers than the others) on average (.19) than the members of CONF (.11) and so forth. The prestige coefficient reflects the user's probability of being followed by someone else (Newman, 2010), its number indicating the popularity of particular groups. However, the mentioned popularity should be considered more as the tendency of entities to point to a given set of users than the prestige. It is more about determining the central position of a particular user or specific group of users in the network ( $\mathrm{Li}, \mathrm{Liu}, \&$ Yao, 2016). To summarize the obtained data, it was worthwhile to determine other basic structural properties of the graph. Structures characterized by the existence of many connections between users support the trust and reciprocity (Granovetter, 2005). To measure how strongly the Polish MPs were connected, the ratio of the number of existing edges and number of possible edges should be calculated; this is called density. The graph density was equal to .15 , meaning that the wiring probability of two randomly chosen nodes was equal to $15 \%$. The homophilic tendency was observed in the case of the obtained data. The following sections of the paper will provide a more detailed picture of Polish MPs' connectivity.

\section{RESULTS}

The structural properties of a network encompass elements that can help to gauge the asymmetry of the communication between actors. The quantification of mutuality representing symmetrically connected pairs of nodes was the point of departure for the analysis. The relation is reciprocal when two actors follow each other. Therefore, the pairwise comparison was employed to examine the reciprocal relations in the obtained network and the maintaining of communication structure by the politicians (Figure 1). The diagonal in the left-side chart (Figure 1-a) depicts the internal connectivity between each group. Although the exact number of edges could be meaningless, the reciprocity coefficient seemed to be sufficient for the analysis

While for instance MPs from CC or UR (United Right) maintained a great number of edges (Figure 1-a), the reciprocity of these connections seems to be weaker than in the much smaller L (Left), PC (Polish Coalition), or even CONF (Confederation) groups (Figure 1-b). The reciprocal relations in each group 


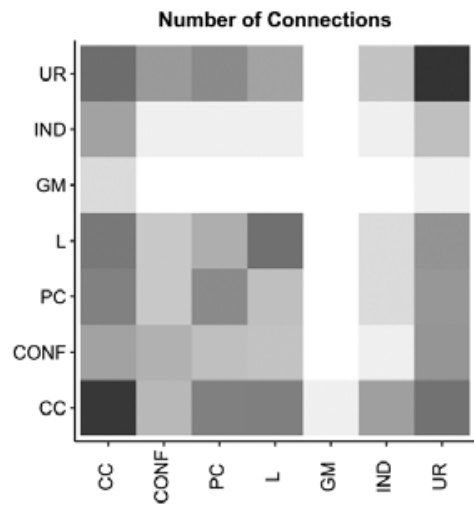

(a)

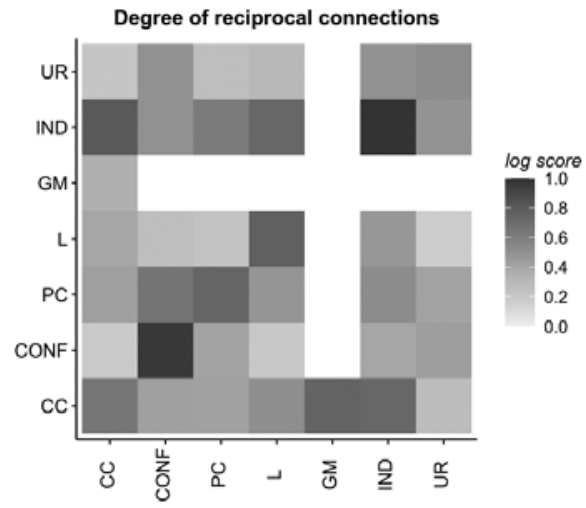

(b)

Figure 1. Communication Structure Establishing by Polish MPs

depict how much those people know about the activity of the others. If a politician affiliated to CC or UR tweets something, the likelihood that others with the same affiliation would see it is (.65) and (.53), respectively. Reciprocal relations facilitate the information flow, immediately extending its effects. Nonetheless, there are many more examples of the way in which the information flow can be limited or extended in Polish MPs' networks. Establishing mutual relations concerning sympathies or antipathies of politicians repeatedly facilitates the information flow between users, who are able to check the updates instantly. The architecture of the Twitter platform does not allow users to see the content of a non-follower unless a mutual connection is established. One can anticipate that the individual possessing many mutually connected relations could be more informed than the others. Unfortunately, misinformation and informational chaos may be the side effect of the reciprocal relations. The diversity of relations and heterogeneity of nodes taking part in communication processes can affect the structural form and its internal functioning.

The next step of the research was to conduct the connectivity test of the MPs' parliamentary group. A special algorithm was chosen for diversifying the graph into stronger and weaker components and as a result divided the entire follower network data into modules - commonly known as communities (Rosvall \& Bergstrom, 2007). Based on previously presented data, and referring to a number 
of edges and mutual connections, we were able to distinguish four communities with individually dominating politically affiliated group features (Table 2).

Table 2. Community Detection within the Entire Network

\begin{tabular}{|l|c|c|c|c|}
\hline Party affiliation & Module 1 & Module 2 & Module 3 & Module 4 \\
\hline CC & $\mathbf{1 4 6}(. \mathbf{9 9})$ & $0(.00)$ & $1(.01)$ & $0(.00)$ \\
\hline CON & $0(.00)$ & $2(.18)$ & $0(.00)$ & $\mathbf{9 ( . 8 2 )}$ \\
\hline PC & $23(.85)$ & $4(.15)$ & $0(.00)$ & $0(.00)$ \\
\hline L & $2(.05)$ & $0(.00)$ & $\mathbf{4 0}(.95)$ & $0(.00)$ \\
\hline GM & $1(1)$ & $0(.00)$ & $0(.00)$ & $0(.00)$ \\
\hline IND & $3(1)$ & $0(.00)$ & $0(.00)$ & $0(.00)$ \\
\hline UR & $4(.02)$ & $\mathbf{1 9 4}(.98)$ & $0(.00)$ & $0(.00)$ \\
\hline
\end{tabular}

Note: Numbers in parentheses depict proportion of all politicians with particular political affiliation.

The image derived from the data resembles real division between the representatives of the ruling coalition and the opposition. The first module is dominated by CC politicians; nonetheless, there are also representatives from PC. Moreover, both independent senators and one politician representing German Minority were included in this community. The second module is dominated by the politicians from UR. Indeed, the use of the Info Map clustering algorithm (Alzahrani \& Horadam, 2016) confirmed that Polish politicians use Twitter mostly for social visibility and marketing or eventual political campaigning. The fourth module is occupied by the Left (L) party. Not surprisingly, the L was qualified as a separate module. The activity of leftist politicians - especially members of the Spring party - are characterized by very liberal, progressive, and feministic ideology, which does not fit with the other groups. The L communication structure, which consists of many fresh and relatively young politicians, has not crystalized yet regarding the popularity of individual politicians. On the other hand, the algorithm has categorized all far-right parties' members to module four. The high degree of reciprocity in internal relations and highly dense structure means that CONF party politicians were embedded in the separate community.

The structural properties corresponding to a number of edges provided explicit information on how the entire MPs' network is divided and how influential specific affiliation groups can be. Four communities indicated by the algorithmic detection reflected the real state of the Polish political scene. It is 
not a coincidence that PC, consisting mainly of the Polish People's Party, found room in Module 1 jointly with CC members that largely include politicians from Civic Platform. They were coalition members from 2007 till 2015. However, one should remember that the Polish MPs structure that crystalized on Twitter may be the result of different factors, not necessarily comprised directly from politicians' activity outside Twitter. This community detection is merely a plausible exemplification of structural properties of the Polish politicians' network.

Investigation of the tendencies of Polish MPs to follow users bearing similar attributes (affiliation factor) was based on the premise that assortative pairing can have a profound effect on the structural properties of a network. Data analysis revealed observable patterns of connections between actors (Table 3 ). Two different measures were used for depicting homophilic tendencies within the network. The first one employed an assortative mating coefficient basing on correlation between attributes that two nodes possess (Newman, 2003). The coefficient gives $r=-1$ for perfect disassortative network, and $r=1$ otherwise. A more positive result indicates more visible and clear evidence of homophily. The second approach was based mainly on exact proportions of all edges that connect nodes with the same characteristics. The assortativity coefficient for the entire network was $r=0.56$, indicating that there was a tendency of the Polish MPs to follow politicians from the same party. The average proportion of group edges that link two nodes with the same affiliation is equal to .72, hence confirming this tendency among Polish MPs.

Table 3. Assortative Mating Patterns and Edge Homophily among Polish MPs

\begin{tabular}{|l|c|c|c|c|c|c|c|}
\hline & CC & CONF & PC & L & GM & IND & UR \\
\hline CC & - & .44 & .34 & .52 & .00 & .00 & .77 \\
\hline CONF & & - & .56 & .66 & .00 & .27 & .26 \\
\hline PC & & & - & .75 & .00 & .09 & .51 \\
\hline L & & & & - & .00 & .11 & .80 \\
\hline GM & & & & & - & .00 & .00 \\
\hline IND & & & & & & - & .02 \\
\hline Internal similarity & .61 & .10 & .16 & .33 & .00 & .01 & .70 \\
\hline Ego homophily M & .80 & .40 & .45 & .55 & .03 & .04 & .86 \\
\hline Ego homophily SD & .12 & .35 & .27 & .18 & - & .03 & .16 \\
\hline
\end{tabular}

Note: $\mathrm{M}=$ Mean, $\mathrm{SD}=$ Standard Deviation. The crosstab depicts correlational assortative mixing patterns between particular parties. The homophily and neighbor's ego analysis was conducted to check the local environment of the nodes. 
The pairwise comparison was made to check the similarity between two groups of nodes included in the subgraphs. Comparison between the two biggest parties, CC and UR, provided explicit evidence of assortativity (.77). This means that MPs from these two groups tend to follow users with the same affiliation rather than the opposition. Strong correlation was also found in the case of PC and L (.75), and L and UR (.80). It is vital that the representatives of the Left party stay "closed" in comparison to right-wing Law and Justice party members. Internal homophily was examined and revealed that the most homophilic in terms of connecting similar nodes was the group of UR politicians (.70). MPs from CONF, PC, L, GM (German Minority), and IND (Independent MPs) tended to more follow politicians characterized by a different party affiliation. This confirmed the degree of prestige of particular groups.

To make the data more insightful, the neighborhood of each single node was also analyzed. The average ego homophily depicts the mean value of local constancy when it comes to node alters. The higher the value, the more homophilic a node followers' environment is. The result for UR (.86) for instance indicates that the vast majority of UR representatives are mostly following their party colleagues, however the density emphasizes the fact that because of the number of UR members, the proportion of existing edges to its maximal number is low (.25).

These data explicitly revealed that the core communication structure based on political actor choices maintained a limited nature in terms of establishing contacts with differentiated nodes. However, as the communication structures are changing all the time, we can assume that a general network structure of Polish MPs on Twitter is in a mature phase at the moment and there is small possibility of significant changes in the network. Follower networks are gradually accumulating; however, they are generally more stable than the micro communication as replies or mentions that change rapidly the Twitter environment (Bruns \& Moe, 2014, pp. 16-20). The analyzed data were limited only to close group of politicians currently active in parliament. Therefore, the expected structure development will be less dynamic than in case of examining the entire environment of individual politicians.

Nonetheless, the structure and action are interrelated in terms of the development of social connections (McQuail, 2010). To verify whether politicians from party-affiliated groups use these specific communication channels, the custom test was conducted using the $\mathrm{R}$ programming language (Figure 2). The data depicts proportions' means derived for each politician bearing specific party 
affiliation. The starting point for recent tweets analysis $(\mathrm{N}=1000)$ was set on May 30, 2020. The data were limited to those that included the “@mention” sign for directing tweets. The test was performed to investigate the information flow of the chosen politicians to the follower structure established on Twitter. The algorithm was limited merely to searches for tweets, replies, quotes, and retweets recently posted by the actors.

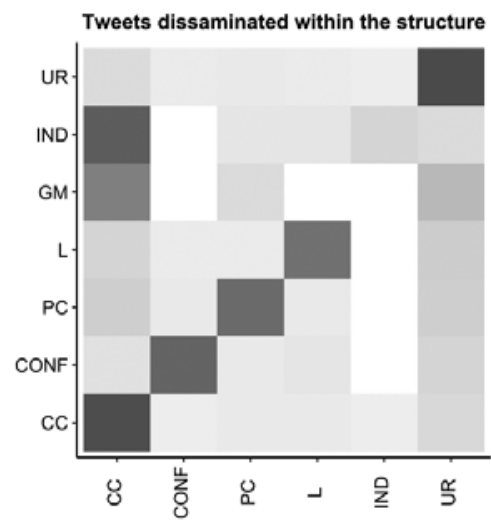

(a)

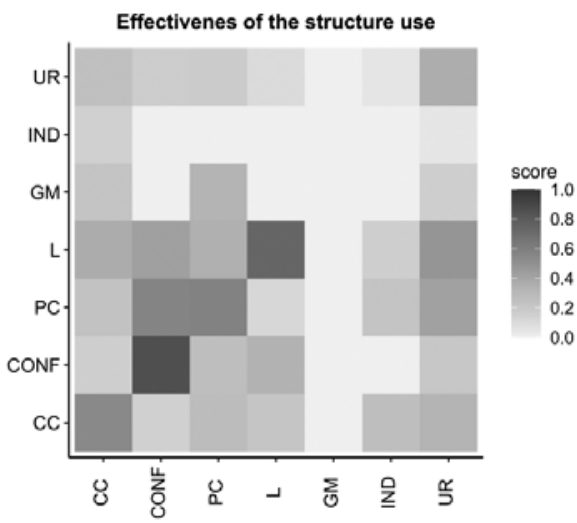

(b)

Figure 2. Communication Structure Establishing by Polish MPs

The analysis provided evidence confirming previous assumptions: politicians from particular groups, regardless of the number of mutual or asymmetrical connections, mostly publish content that is internally oriented (Figure 2-a). German Minority deputy and Independent senators, who tweeted mostly to CC politicians, seemed to be the exception. In terms of tweets proportion published by PC representatives, there were (.16) tweets on average toward CC politicians. However, CC members did not mention PC politicians frequently. Dividing the considerations into structure and action directs one's attention to the general purpose of such communication. In many cases, homophily of the structure causes politicians to tweet something towards the same or different group of users. In turn, these inter and intra levels of communication determine the dynamics of the network. Therefore, an increasing presence of inter-communication (diagonal data in Figure 2-a) strengthens the homophily, and is related to the cooperation of individual party members. On the other hand, a prominence of intra edges 
connecting two groups could indicate implicit cooperation within coalition or between oppositional parties (for instance, visible cooperation of GM and IND with CC), or asymmetrical relation bearing the hallmarks of political struggle (Blumler \& Gurevitch, 1995). Polish MPs' Twitter communication networks are homophilic in both structure and action.

Employing multifaceted filtering $\mathrm{R}$ code, it was possible to provide a more detailed picture of communication structure effectiveness concerning follower base use (Figure 2-b). The results are based on a fraction of 429 Twitter actors' interactions towards actors they followed and the follower base that each actor possessed. Not surprisingly, an assortative pattern was observed in terms of the average proportion of individual follower's contacts.

Assortative mixing is a result of social influence (inverse tendency of adopting certain behavior from social contacts) and homophily (Šćepanović et al., 2017). Specific use of individual follower bases depends on external factors coming from outside the structure (Leenders, 1997). Speech in the parliament, political debate, or interview with the political actor can diametrically change the structural focus and affect changes in the core network as well. The analysis revealed strong patterns of homophily among Polish MPs. Each group of politicians to some extent were found to use their external connections, however internal communication and tendency to connect similar attributed actors is still more observable. CONF politicians seemed to be more encouraging in internal communication than the other actors (.86). It was mainly caused by the number of deputies from this particular group (11). Similarly, actors associated with PC and $\mathrm{L}$ tended to maintain contact with party members more than CC and UR groups. Interestingly, the polarization of IND and GM interactions was noticeable. Regardless of their being a small number of actors (three for IND and one for GM), these groups distributed their content between politicians from the biggest parties they followed. Analysis of the use of actors followed by each user ensures plausible evidence of affiliation homophily among Polish MPs.

Considerations of homophily concern the problem of group connectivity. Homophily of a particular network can change over time or under given conditions, since users can reconfigure networks. Communication structure is not static but dynamic. Since the number of specific links is the leading factor that can affect variability in assortative mating patterns, it is worthwhile to check whether the change in its number implies changes in the degree of homophily.

To test the stability of homophilic behaviour in a single group of affiliated deputies, a network induction simulation was conducted (Figure 3 ). The main 
aim of this measurement was to check how the homophily of individual modules would change if its coreness threshold increased. Coreness $(k$-core) corresponds to the maximal connected subgraph in which each node has at least degree $k$. The purpose of this coefficient is to verify connectivity of a graph.

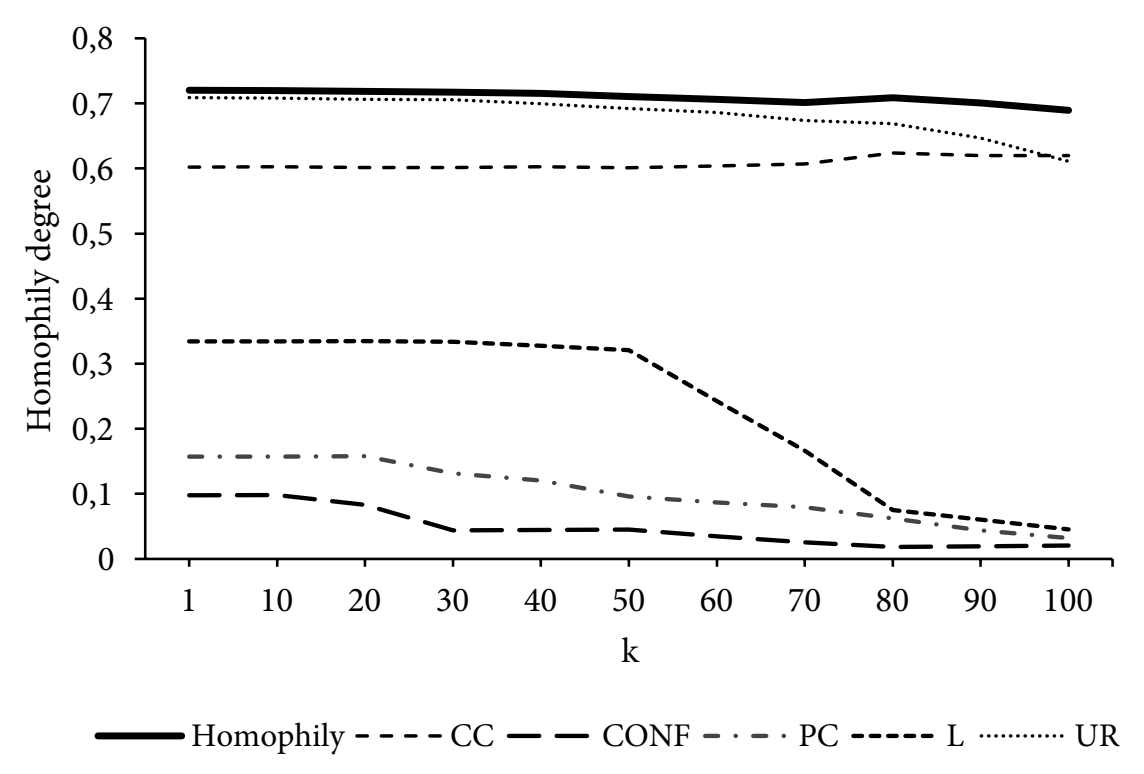

Figure 3. Network Induction Simulation Based on the Network Coreness

Note: The coefficient for the depicted graph is equal to $\mathrm{k}=100$. IND and GM were meaningless for the analysis.

The simulation explicitly confirmed the strength of the two biggest components (CC and UR). The analysis provided evidence that the connectivity of the two biggest party members was much more stable than in other cases. Modification of a number of edges did not cause significant changes in the homophily of these groups. Homophily of PC and CONF for instance was successively decreasing from the $k=15$. The L party members maintained internal homophilic tendencies till $k=50$. Their connectiveness was caused by the edges number as well as being part of a separate module enhancing the stability interval of homophily. The data derived from the simulation provided evidence that the focus on ego homophily coefficient matters in this case. The network simulation employed the pivot conception of the network, that is, coreness. Hence, 
the homophily degree was the result of the existence of the network's strongest component. The decreasing level of homophily in each group except CC can be explained by their coreness distribution. Assuming that the $k=100$ is a maximal subgraph we can obtain, the distribution of users affiliated with individual parties that possess coreness in the range of $0<k \leq 100$ should be examined.

The differences between groups are clearly seen in the average coreness level. There were 88 politicians from CC in the maximal subgraph, with average coreness equal to $(\mathrm{M}=84.19, \mathrm{SD}=29)$. In comparison, there were 80 politicians from UR in the maximal subgraph, and the mean coreness for this group equalled ( $M$ $=72.21, \mathrm{SD}=33.57)$. For $\mathrm{L}$, the average coreness of its representatives equalled $\mu$ $=69.36$, and deviation $\sigma=21.47$. The observable drop in homophily in the case of $\mathrm{L}$ was caused by fact that most of the leftish representatives were distributed in the range of $50<k \leq 80$. Thus, the connectivity of this group did not allow for maintaining stable homophily. Only the six best connected L representatives were included in the final induced network with $k=100$. According to other groups, the analysis provided similar correlation between decreasing homophily and the drop of nodes and edges. The final induced network consisted of 7 PC representatives $(M=69.81, S D=29.53)$ and only 4 CONF deputies $(M=64, S D$ $=34.68$ ). Strong internal connectivity of the two biggest parties was observable in terms of maintaining the homophily. Not surprisingly, the communication structure was found to be oscillating around the two main groups of actors from CC and UR that set the directions of network formulation.

\section{CONCLUSION}

The network approach provided irrefutable examples of homophilic online behavior and connectivity of Polish MPs on Twitter. Responding to the first research question, partisanship was found as an important factor strongly affecting politicians' tendency to follow and be followed by similar attributed individuals. Nominal assortativity analysis was conducted simultaneously for two parliament chambers; however, the effect was not meaningful and indicated no distinct patterns of homophily.

Assortative mixing patterns and internal edge homophily among Polish MPs indicated the existence of partisan echo chambers relevant in content dissemination through the existing communication structure. This was confirmed through the tweets' analysis. The structural homophily has a great impact on 
how politicians from given parties communicate (Passe, Drake, \& Mayger, 2018). Regardless of changing communication environments, homophilic behavior was observed in terms of the followers' structure use, which responds to RQ5. However, the main constraint of the study concerned the scope of the analysis being merely limited to a number of interactions between politicians, excluding the content of the tweets. Nonetheless, with knowledge about communication structure and relatively high network homophily, one can anticipate the amount of information characteristic of particular node groups. From the perspective of political communication, however, a high level of polarization, diversification, and fragmentation of the opinions of users is noticeable (Marozzo \& Bessi, 2017). Data analysis exposed the bipolarity of the network structure, where the influence is shared mainly between two main groups of politicians associated with Civic Coalition and United Right.

Answering the third research question, the polarization is visible strictly in regards to communication structure use (RQ3). In the vast majority, representatives of each group communicate internally according to their homophilic tendencies. Second, they use external links to remain communicative with other politicians. Nonetheless, the examined content disseminated through Twitter by all current Polish MPs gravitates toward the two biggest modules, dominated by CC and UR. This bipolar type of network clearly affects information flow among Polish political actors. Simulations conducted in the research explicitly depicted that high connectivity and the number of included nodes in the community can lead to maintaining homophily (RQ4). Mutual relations predominance implies diversification of communities' elements that encompass particular party members. The network consisted of four modules based on reciprocity and density of relations (RQ2).

The present study is only an introduction to more extensive analyses of political communication structures on Twitter. Relatively easy access to comprehensive data has opened up new analytical possibilities on both a national and international scale. Therefore, future research should integrate an external comparative aspect focusing on structures specific to different countries. Nevertheless, the restrictions imposed in the research process, related to the lack of analysis of the content of tweets, did not affect the significance of the study in presenting a reflection of political and social relations in the Polish Twittersphere. 


\section{APPENDIX: LIST OF POLISH POLITICAL PARTIES/ALLIANCES WITH REPRESENTATIVES IN THE PARLIAMENT:}

L\&J - Law and Justice - Prawo i Sprawiedliwość (ruling party)

CC - Civic Coalition - Koalicja Obywatelska

PC - Polish Coalition - Koalicja Polska

UR - United Right - Zjednoczona Prawica

CONF - Confederation - Konfederacja

L - Left - Lewica

GM - German minority - Mniejszość niemiecka

IND - Independent MPs - senatorowie niezależni

\section{REFERENCES:}

Ahmed, S., Jaidka, K., \& Cho, J. (2016). The 2014 Indian Elections on Twitter: A Comparison of Campaign Strategies of Political Parties. Telematics and Informatics. 33(4), 1071-1087. DOI: 10.1016/j.tele.2016.03.002.

Alzahrani, T., \& Horadam, K.J. (2016). Community Detection in Bipartite Networks: Algorithms and Case studies. In: J. Lü, X. Yu, G. Chen, \& W. Yu (Eds.). Complex Systems and Networks: Dynamics, Controls and Applications (pp. 25-50). Berlin, Heidelberg: Springer.

Baranowski, P. (2015). Online Political Campaigning During the 2014 Regional Elections in Poland. Media and Communication, 3(4), 35-44. DOI: 10.17645/mac. v3i4.368.

Blumler, J., \& Gurevitch, M. (1995). The Crisis of Public Communication. London-New York: Routledge.

Brandes, U., \& Erlebach, T. (Eds.) (2005). Network Analysis: Methodological Foundations. Lecture Notes in Computer Science, 3418. Berlin, Heidelberg: Springer.

Bruns, A. (2017, September 14-15). Echo Chamber? What Echo Chamber? Reviewing the Evidence. Conference Paper from $6^{\text {th }}$ Biennial Future of Journalism Conference (FOJ17). Cardiff. Retrieved June 17, 2020 from: https://eprints.qut.edu.au/113937/.

Bruns, A., \& Moe, H. (2014). Structural Layers of Communication on Twitter. In: K. Weller, A. Bruns, J. Burgess, M. Mahrt, \& C. Puschmann (Eds.). Twitter and Society (pp. 15-28). New York, NY: Peter Lang.

Bruns, A., \& Highfield, T. (2016). Is Habermas on Twitter? Social Media and the Public Sphere. In: A. Bruns, G. Enli, E. Skogerbo, A. Larsson, \& C. Christensen (Eds.). The Routledge Companion to Social Media and Politics (pp. 56-72). Abingdon, UK: Routledge. 
Carrington, P. (2014). Social Network Research. In: S. Dominguez, \& B. Hollstein (Eds.). Mixed Methods Social Networks Research: Design and Applications (pp. 35-64). New York, NY: Cambridge University Press. DOI: 10.1017/CBO9781139227193.004.

Casero-Ripollés, A., Sintes-Olivella, M., \& Franch, P. (2017). The Populist Political Communication Style in Action: Podemos's Issues and Functions on Twitter during the 2016 Spanish General Election. American Behavioral Scientist, 61(9), 986-1001. DOI: $10.1177 / 0002764217707624$.

Cheng, J., Romero, D., Meeder, B., \& Kleinberg, J. (2011). Predicting Reciprocity in Social Networks. In: 2011 IEEE Third International Conference on Privacy, Security, Risk and Trust and 2011 IEEE Third International Conference on Social Computing (pp. 49-56). Boston, Ma. DOI: 10.1109/PASSAT/SocialCom.2011.110.

Cogburn, D.L., \& Espinoza-Vasquez, F.K. (2011). From Networked Nominee to Networked Nation: Examining the Impact of Web 2.0 and Social Media on Political Participation and Civic Engagement in the 2008 Obama Campaign. Journal of Political Marketing, 10(1-2), 189-213. DOI: 10.1080/15377857.2011.540224.

Contractor, N.S., Wasserman, S., \& Faust, K. (2006). Testing Multitheoretical, Multilevel Hypotheses about Organizational Networks: An Analytic Framework and Empirical Example. Academy of Management Review, 31(3), 681-703. DOI: 10.5465/ amr.2006.21318925.

Czyżowski, D., \& Porębski, L. (2017). Media społecznościowe w kampanii wyborczej. Wykorzystanie Twittera w polskich wyborach parlamentarnych w roku 2015 [Social Media in Electoral Campaigns: The Use of Twitter in Polish Parliamentary Elections in 2015]. Studia Politologiczne, 45, 165-179.

Dahl, R.A. (1998). On Democracy. New Haven \& London: Yale University Press.

Del Valle, M.E., \& Bravo, R.B. (2018). Echo Chambers in Parliamentary Twitter Networks: The Catalan Case. International Journal of Communication, 12, 1715-1735.

Dobek-Ostrowska, B. (2017). Towards Professionalization and Americanization: Audiovisual Political Advertising in Poland (1989-2015). In: C. Holtz-Bacha, \& M.R. Just (Eds.). Routledge Handbook of Political Advertising (pp. 397-408). New York-London: Taylor \& Francis.

Granovetter, M.S. (2005). The Impact of Social Structure on Economic Outcomes. Journal

of Economic Perspectives, 19(1), 33-50. DOI: 10.1257/0895330053147958.

Hollstein, B. (2011). Qualitative Approaches. In: J. Scott, \& P.J. Carrington (Eds.). Sage Handbook of Social Network Analysis (pp. 404-416). London: Sage.

Hong, S., \& Kim, S.H. (2016). Political Polarization on Twitter: Implications for the Use of Social Media in Digital Governments. Government Information Quarterly, 33(4), 777-782. DOI: 10.1016/j.giq.2016.04.007.

Iacobucci, D. (1994). Graphs and Matrices. In: S. Wasserman, \& K. Faust (Eds.). Social Network Analysis: Methods and Applications (pp. 92-166). New York: Cambridge University Press. DOI: 10.1017/CBO9780511815478.005.

Jungherr, A. (2014). The Logic of Political Coverage on Twitter: Temporal Dynamics and Content. Journal of Communication, 64(2), 239-259. DOI: 10.1111/jcom.12087. 
Jungherr, A. (2016). Twitter Use in Election Campaigns: A Systematic Literature Review. Journal of Information Technology \& Politics, 13(1), 72-91. DOI: 10.1080/19331681.2015.1132401.

Lazarsfeld, P.F., \& Merton, R.K. (1954). Friendship as a Social Process: A Substantive and Methodological Analysis. Freedom and Control in Modern Society, 18(1), 18-66.

Lee, E., Karimi, F., Jo, H.-H., Strohmaier, M., and Wagner, C. (2017). Homophily explains perception biases in social networks. arXiv preprint: arXiv:1710.08601.

Leenders, R.Th.A.J. (1997). Longitudinal Behavior of Network Structure and Actor Attributes: Modeling Interdependence of Contagion and Selection. In: P. Doreian, \& F. Stokman (Eds.). Evolution of Social Networks (pp. 165-184). London: Routledge.

Li, X., Liu, Y., \& Yao, M. (2016). Openness, Activeness, and Diversity of Information Exchange in the Context of Online Social Networks. In: X. Li (Ed.). Emerging Media: Uses and Dynamics. New York: Routledge.

Marciniak, E.M. (2020). Społeczna percepcja wyborów 2019 roku. [Social Perception of Election in 2019]. Studia Politologiczne, 55, 309-322. DOI: 10.33896/ SPolit.2020.55.14.

Marozzo, F., \& Bessi, A. (2017). Analyzing Polarization of Social Media Users and News Sites during Political Campaigns. Social Network Analysis and Mining, 8(1), 1-13. DOI: $10.1007 / \mathrm{s} 13278-017-0479-5$.

Massa, P. (2011). Trust It Forward: Tyranny of the Majority or Echo Chambers? In: H. Massum, \& M. Tovey (Eds.). The Reputation Society: How Online Opinions Are Reshaping the Offline World (pp. 151-161). Cambridge: The MIT Press.

Matuszewski, P., \& Szabó, G. (2019). Are Echo Chambers Based on Partisanship? Twitter and Political Polarity in Poland and Hungary. Social Media + Society, 5(2), 1-14. DOI: $10.1177 / 2056305119837671$.

McPherson, M., Smith-Lovin, L., \& Cook, J.M. (2001). Birds of a Feather: Homophily in Social Networks. Annual Review of Sociology, 27(1), 415-444. DOI: 10.1146/ annurev.soc.27.1.415.

McQuail, D. (2010). McQuail's Mass Communication Theory (6 ${ }^{\text {th }}$ Ed.). Los Angeles: Sage Publications.

Messing, S., \& Westwood, S.J. (2014). Selective Exposure in the Age of Social Media: Endorsements Trump Partisan Source Affiliation When Selecting News Online. Communication Research, 41(8), 1042-1063. DOI: 10.1177/0093650212466406.

Newman, M.E.J. (2002). Assortative Mixing in Networks. Physical Review Letters, 89(20), 208701. DOI: 10.1103/PhysRevLett.89.208701.

Newman, M.E.J. (2003). Mixing Patterns in Networks. Physical Review E, 67(2), 026126. DOI: 10.1103/PhysRevE.67.026126.

Newman, M.E.J. (2010). Networks: An Introduction. New York: Oxford University Press. Papacharissi, Z. (2008). The Virtual Sphere 2.0: The Internet, the Public Sphere, and Beyond. In: A. Chadwick, \& P.N. Howard (Eds.). Routledge Handbook of Internet Politics (pp. 230-245). London-New York: Routledge. 
Park, C.S. (2013). Does Twitter Motivate Involvement in Politics? Tweeting, Opinion Leadership, and Political Engagement. Computers in Human Behavior, 29(4), 1641-1648. DOI: 10.1016/j.chb.2013.01.044.

Passe, J., Drake, C., \& Mayger, L. (2018). Homophily, Echo Chambers, \& Selective Exposure in Social Networks: What Should Civic Educators Do? The Journal of Social Studies Research, 42(3), 261-271. DOI: 10.1016/j.jssr.2017.08.001.

Poulakidakos, S., \& Veneti, A. (2016). Political Communication and Twitter in Greece: Jumps on the Bandwagon or an Enhancement of the Political Dialogue? In: T. Deželan, \& I. Vobič (Eds.). (R)evolutionizing Political Communication through Social Media (pp. 119-146). Hershey: IGI Global. DOI: 10.4018/978-1-4666-9879-6. ch007.

Rosvall, M., \& Bergstrom, C.T. (2007). Maps of Information Flow Reveal Community Structure in Complex Networks. PNAS U.S.A., 105(4), 1118-1123.

Šćepanović, S., Mishkovski, I., Gonçalves, B., Nguyen, T.H., \& Hui, P. (2017). Semantic Homophily in Online Communication: Evidence from Twitter. Online Social Networks and Media, 2, 1-18. DOI: 10.1016/j.osnem.2017.06.001.

Schmidt, J.H. (2014). Twitter and the Rise of Personal Publics. In: K. Weller, A. Bruns, J. Burgess, M. Mahrt, \& C. Puschmann (Eds.). Twitter and Society (pp. 3-14). New York, NY: Peter Lang.

Schulz, W. (2014). Political Communication in Long-Term Perspective. In: C. Reinemann (Ed.). Political Communication (pp. 63-85). Berlin: Walter de Gruyter. DOI: 10.1515/9783110238174.63.

Scott, A.J. (2000). The Cultural Economy of Cities: Essays on the Geography of ImageProducing Industries. London: Sage.

Spohr, D. (2017). Fake News and Ideological Polarization: Filter Bubbles and Selective Exposure on Social Media. Business Information Review, 34(3), 150-160. DOI: $10.1177 / 0266382117722446$.

Stier, S., Bleier, A., Lietz, H., \& Strohmaier, M. (2018). Election Campaigning on Social Media: Politicians, Audiences, and the Mediation of Political Communication on Facebook and Twitter. Political Communication, 35(1), 50-74. DOI: 10.1080/10584609.2017.1334728.

Stroud, N.J. (2008). Media Use and Political Predispositions: Revisiting the Concept of Selective Exposure. Political Behavior, 30(3), 341-366. DOI: 10.1007/s11109007-9050-9.

Sunstein, C.R. (2009). Republic.Com 2.0. Princeton-Oxford: Princeton University Press. Szafraniec, K., \& Grygieńć, J. (2019). Prawicowość młodych Polaków. Kontekst wyborów parlamentarnych z 2015 roku [The Right-Wing Attitudes of Young Poles: The Context of the 2015 Parliamentary Elections]. Studia Socjologiczne, 2, 5-35. DOI: $10.24425 /$ sts.2019.126138.

Szczerbiak, A. (2019a). Why Is Poland's Law and Justice Party Still So Popular? LSE European Politics and Policy (EUROPP) Blog. Retrieved June 15, 2020 from: https:// blogs.lse.ac.uk/europpblog/2019/10/01/why-is-polands-law-and-justice-party-stillso-popular/. 
Szczerbiak, A. (2019b). Who Will Win the Polish Election? LSE European Politics and Policy (EUROPP) Blog. Retrieved January 15, 2021 from: https://blogs.lse.ac.uk/ europpblog/2019/10/08/who-will-win-the-polish-election/.

Uslaner, E.M. (2004). Trust, Civic Engagement, and the Internet. Political Communication, 21(2), 223-242. DOI: 10.1080/10584600490443895.

Vaccari, C., Valeriani, A., Barberá, P., Jost, J.T., Nagler, J., \& Tucker, J.A. (2016). Of Echo Chambers and Contrarian Clubs: Exposure to Political Disagreement among German and Italian Users of Twitter. Social Media + Society, 2(3), 1-24. DOI: $10.1177 / 2056305116664221$.

Woźniak, A. (2015, November 16). Dlaczego Twitter jest $w$ Polsce narzędziem dziennikarzy i polityków? [Why Is Twitter the Tool for Journalists and Politicians?]. Retrieved May 10, 2020 from: https://nowymarketing.pl/a/7572,dlaczego-twitterjest-w-polsce-narzedziem-dziennikarzy-i-politykow.

Zagała, Z. (2020). Partie polityczne i ich elektoraty. Od sympatii do antagonizmu. Na przykładzie Platformy Obywatelskiej i Prawa i Sprawiedliwości [Political Parties and Their Electorates: From Sympathy to Antagonism. On the Example of Civic Platform and Law and Justice]. Przeglad Politologiczny, 25(2), 193-205. DOI: 10.14746/pp.2020.25.2.14.

Zhang, H., Dantu, T., \& Cangussu, J. (2009). Quantifying Reciprocity in Social Networks. 2009 International Conference on Computational Science and Engineering (pp. 1031-1035). Vancouver, BC, Canada: IEEE. DOI: 10.1109/CSE.2009.399. 